\title{
Kebijakan Stock Split Perusahaan Non-Financial Di Indonesia: Manajemen Laba, Kinerja Operasi, Kinerja Pasar
}

\author{
Titi Sari Indriani ${ }^{1)}$, Amrie Firmansyah ${ }^{2)}$ \\ Politeknik Keuangan Negara STAN \\ $\underline{\text { titisa1819@gmail.com }{ }^{1)}}$, amrie@ pknstan.ac.id ${ }^{2}$
}

$\begin{array}{ll}\text { Dikirim } & : \text { 29 Juni } 2021 \\ \text { Diterima } & : \text { 11 Juli } 2021 \\ \text { Dipublikasikan } & : \text { 1 Agustus } 2021\end{array}$

\begin{abstract}
The stock split policy shows the success of managers in managing the company. The condition of managers who have perfect information compared to shareholders, stock split policies may coincide with certain motives carried out by managers. This study examines differences in earnings management, operating performance, and market performance before and after the company conducts a stock split. This study employs secondary data sourced from www.idx.co.id, www.idnfinansials.com, and www.finance.yahoo.com. The data employed consists of data and information from financial statements and stock prices of non-financial companies listed on the Indonesia Stock Exchange from 2013 to 2019. The sample used in this study amounted to 64 observations based on purposive sampling. The data analysis test used the normality test and the Wilcoxon matched-pairs test. This study concludes that earnings management and market performance increase after the company's stock split is carried out. Meanwhile, operating performance did not experience any difference before and after the stock split was carried out. This study proves that managers employ the moment stock split to carry out earnings management for certain motives, even though the market participants positively respond to these actions. The companies that carry out stock splits should make these events to improve their operating performance. This study indicates that the Financial Services Authority needs to review companies with plans to conduct a stock split to protect investors in the capital market.
\end{abstract}

\section{Keywords: Earnings Quality; Market Response; Operating Performance}

\section{PENDAHULUAN}

Dunia pasar modal global belakangan ini mengalami naik turun yang sangat cepat akibat pandemi Covid-19, khususnya di awal tahun 2020 saat itu ketika pasar saham dunia sedang berada pada puncaknya di bulan februari 2020, wabah pandemi tiba-tiba muncul dan memicu jatuhnya harga saham setelahnya. Penyebaran Covid-19 juga sangat berdampak pada pasar ekuitas global termasuk pasar modal india yang telah mengalami beberapa fase penurunan parah semenjak pandemi ini dimulai (www.financialexpress.com). Sementara itu pada tahun 2021, S\&P 500 naik hingga 56\% dalam jangka waktu setahun, selain itu ada banyak pergerakan-pergerakan kecil pasar saham yang tidak diprediksi sebelumnya (Quast, 2021). Kondisi ini menunjukkan bahwa pasar modal dapat berubah sewaktu-waktu dan tidak dapat diprediksi dalam jangka pendek khususnya pada kondisi belakangan ini. Beberapa industri seperti perbankan, media, real estate, perdagangan dan industri teknik mengalami banyak penurunan, sementara industri yang bergerak dalam bidang kimia, farmasi, layanan IT dan telekomunikasi memiliki potensi untuk naik selama periode lockdown (www.financialexpress.com, 2021).

Pandemi Covid-19 tidak menurunkan minat investor untuk berinvestasi, namun investor lebih berhati-hati dalam menentukan pilihan investasi pada industri tertentu (Tambunan, 2020). Selama masa pandemi Covid-19, minat masyarakat dalam berinvestasi melalui saham semakin meningkat (https://investasi.kontan.co.id). Kondisi ini didukung dengan mudahnya akses informasi 
dan sederhananya prosedur pembelian saham. PT. BEI melaporkan jumlah investor pasar modal Indonesia yang tercatat pada PT. Kustodian Sentral Efek Indonesia (KSEI) per Juli 2020 telah bertumbuh sebesar 22\% dari tahun 2019 menjadi 3,02 juta investor dengan $42 \%$ diantaranya merupakan investor saham (Tari, 2020).

Tujuan perusahaan go public adalah untuk mendapatkan sumber pendanaan dari saham adalah untuk meningkatkan nilai perusahaan dan memperoleh potensi untuk pertumbuhan perusahaan di masa mendatang (Ismail, 2021). Untuk menarik minat investor dalam berivestasi dan mempertahankan investor lama, corporate action menjadi salah satu alternatif kebijakan perusahaan (www.mncsekuritas.id). Salah satu aksi korporasi yang dilakukan oleh perusahaan adalah stock split atau pemecahan saham. Stock split adalah proses dimana korporasi menurunkan nilai par atau stated value dari sahamnya yang terdiri dari saham yang belum dan telah diterbitkan serta treasury shares (Warren et al., 2016). Stock split tidak memiliki efek pada share capital, share premium, retained earnings, ataupun total ekuitas (Weygandt et al., 2015), sehingga stock split tidak memiliki nilai ekonomis yang berperan dalam proses operasional perusahaan. Namun, aktivitas stock split terus dilakukan di Bursa Efek Indonesia selama periode tahun 2013-2019, dengan rata-rata terdapat 12 perusahaan yang melakukan stok split setiap tahunnya (www.idx.co.id).

Investor tidak dapat mengetahui secara pasti alasan atau motif sebenarnya ketika agen mengambil kebijakan untuk melakukan stock split. Sebenarnya, stock split tidak menimbulkan dampak yang ekonomis bagi perusahaan, namun mungkin saja terdapat motif-motif lain atau tujuan implisit dari manajer atas aktivitas ini. Adanya informasi asimetri antara manajer dan pemilik perusahaan mengakibatkan motif adanya stock split hanya diketahui oleh manajer. Manajer mungkin ingin mengalihkan perhatian pemegang saham atas kinerjanya yang optimal sehingga motif tujuan utama adanya kebijakan stock split tersebut tidak diketahui oleh pemegang saham. Oleh karena itu, penelitian terkait dengan kebijakan perusahaan dalam melakukan stock split perlu untuk diinvestigasi lebih lanjut.

Penelitian-penelitian sebelumnya telah membahas kebijakan stock split terkait dengan kondisi-kondisi yang terjadi dalam perusahaan seperti harga saham (Puspita \& Yuliari, 2019; Pratiwi et al, 2020), likuiditas (Hadiwijaya \& Widjaja, 2018; Adisetiawan \& Atikah, 2018; Bagaskoro et al, 2019; Burnwal \& Rakshit, 2019), tingkat pengembalian (Adisetiawan \& Atikah, 2018; Hadiwijaya \& Widjaja, 2018; Puspita \& Yuliari, 2019; Nurdin \& Abdani, 2020; Tanoyo, $\underline{2020}$ ), volume perdagangan (Prijati \& Rachmawati, 2019, Tanoyo, 2020), pemberian sinyal perusahaan (Boermawan \& Siregar, 2013; Paramitha, 2019; Cui et al., 2020) dan manajemen laba (Boermawan \& Siregar, 2013; Yagüe et al., 2009; Chan et al., 2019)

Walaupun terdapat adanya perbedaan kepentingan antara manajer dan pemegang saham dalam menjalankan perusahaan (Thakur, 2021), motif-motif manajer dalam melakukan stock split penting untuk diketahui. Stock split menunjukkan bahwa manajer memiliki kinerja operasi dan kinerja pasar yang baik, sehingga manajer berani mengambil kebijakan tersebut. Manajer sebagai agen memiliki peran untuk menjalankan perusahaan dengan konsep going concern yaitu manajer harus dapat memahami dan memberikan keputusan mengenai keberlangsungan usahanya (Sari, 2018). Kebijakan stock split diharapkan dapat memotivasi manajer untuk memiliki kinerja yang optimal di masa depan dan tetap mendapatkan kepercayaan pemegang saham. Namun, terdapat kemungkinan lainnya ketika manajer memiliki informasi yang lebih sempurna dibandingkan dengan pemegang saham yaitu tindakan manajemen laba. Adanya diskresi kebijakan akrual manajer dan adanya informasi asimetri mengakibatkan manajer melakukan manajemen laba (Firmansyah \& Irawan, 2018; Firmansyah \& Irawan, 2019).

Manajemen laba memanfaatkan turan akuntansi untuk diterapkan dan menciptakan laporan keuangan yang menggelembungkan atau memuluskan laba (Tuovila, 2020). Praktek manajemen laba dipengaruhi oleh konflik antara kepentingan manajemen dan pemegang saham yang timbul karena setiap pihak berusaha untuk mencapai atau mempertimbangkan tingkat kemakmuran yang dikehendakinya (Scott, 2015). Dalam suatu kontrak perjanjian kerja, investor memiliki motivasi untuk mendapatkan profit sedangkan manajemen memiliki motivasi untuk memperoleh insentif dari prinsipal (investor) atas pekerjaannya. Kebijakan stock split yang dilakukan perusahaan merupakan suatu alat untuk mencapai tujuan manajemen yaitu untuk meningkatkan laba dengan 
melakukan manajemen laba. Penelitian oleh Chan et al. (2019) menunjukkan adanya peningkatan kecil manajemen laba setelah dilakukan stock split. Sementara itu, penelitian oleh Boermawan \& Siregar (2013) menyatakan bahwa perusahaan yang melakukan stock split terbukti melakukan manajemen laba untuk meningkatkan laba yang kemungkinan disebabkan adanya upaya perusahaan untuk menyampaikan sinyal positif melalui stock split. Namun, Yagüe et al. (2009) menyimpulkan bahwa adanya peningkatan laba yang relatif lebih baik setelah stock split bukanlah hasil dari praktik manajemen laba. Dengan demikian, tindakan manajemen laba dalam kebijakan stock split perusahaan perlu diinvestigasi lebih lanjut.

Selanjutnya, tindakan stock split menunjukkan bahwa manajer ingin menunjukkan bahwa kinerja operasional dalam kondisi yang optimal. Kinerja operasional menjadi dasar bagi perusahaan untuk tetap beroperasi di masa depan. Hermawan (2017) dan Boedhi \& Lidharta (2011) menemukan bahwa terdapat perbedaan atas kinerja operasi perusahaan sebelum dan sesudah dilakukan stock split. Sebaliknya, Soureka \& Muchlis (2013) dan Dwilita \& Satrya (2018) menyimpulkan bahwa tidak terdapat adanya perbedaan kinerja operasi perusahaan sebelum dan sesudah dilakukan stock split. Adanya perbedaan hasil pengujian sebelumnya mengakibatkan pengujian kembali kinerja operasi sebelum dan setelah stock split perlu untuk diinvestigasi kembali.

Sementara itu, kebijakan stock split juga menunjukkan bahwa manajer mendapatkan keyakinan terkait dengan respon pasar yang ditunjukkan melalui kinerja pasar. Pasar akan merespon positif apabila terdapat jaminan kelangsungan perusahaan di masa mendatang yang lebih pasti. Yaasiin (2017), Hadiwijaya \& Widjaja (2018), Puspita \& Yuliari (2019) dan (Tanoyo, 2020) menemukan bahwa terdapat adanya perbedaan kinerja pasar sebelum dan setelah dilakukan stock split. Sebaliknya, Soureka \& Muchlis (2013), Prijati \& Rachmawati (2019), dan Bagaskoro et al. (2019) menunjukkan terdapat perbedaan kinerja pasar sebelum dan setelah dilakukan stock split. Perbedaan hasil pengujian sebelumnya mengakibatkan pengujian kembali kinerja pasar sebelum dan setelah stock split perlu untuk dilakukan. Kebijakan stock split secara umum mengakibatkan peningkatan kinerja operasional dan kinerja perusahaan yang lebih baik. Dari sisi internal, manajer memiliki strategi perusahaan yang lebih baik setelah kebijakan stock split dilakukan. Dari sisi eksternal, kebijakan stock split yang dilakukan oleh perusahaan menunjukkan ada kepercayaan investor atas masa depan perusahaan. Oleh karena itu, investor akan merespon positif kebijakan tersebut.

Penelitian ini bertujuan untuk menginvestigasi perbedaan manajemen laba, kinerja operasi dan kinerja pasar pada kondisi sebelum dan sesudah dilakukan stock split. Penelitian mengenai pengaruh stock split terhadap manajemen laba perusahaan belum banyak dilakukan. Dalam penelitian Boermawan \& Siregar (2013), uji beda manajemen laba sebelum dan sesudah stock split dilakukan menggunakan one sample test, sedangkan dalam penelitian ini uji beda dilakukan dengan paired sample t test sehingga subjek data penelitian yang digunakan sama. Manajemen laba penting untuk diuji perbedaannya sebelum dan setelah perusahaan melakukan stock split mengingat informasi laba adalah informasi yang mudah untuk digunakan oleh investor dalam menilai kinerja manajer dalam aktivitas operasi selama satu periode. Walaupun tidak melanggar ketentuan dalam standar akuntansi keuangan, tindakan manajemen laba yang dilakukan oleh manajer melalui akrual diskresioner, mengakibatkan informasi laba yang digunakan oleh investor menjadi menyesatkan dalam pengambilan keputusan. Oleh karena itu, pengujian manajemen laba sebelum dan sesudah stock split relevan dengan pengujian kinerja operasional dan kinerja pasar.

\section{Teori Agensi}

\section{STUDI LITERATUR}

Bahasan utama dalam teori agensi berfokus pada hubungan antara dua pihak yaitu prinsipal (investor) dan agen (manajer), Jensen \& Meckling, (1976) mendefinisikan hubungan agensi sebagai kontrak antara satu atau lebih orang (prinsipal) yang melakukan perjanjian dengan orang lain (agen) untuk melakukan beberapa pelayanan/tindakan sebagai bentuk dari pendelegasian atas otoritas untuk membuat keputusan kepada agen. Scott, 2015 menyatakan bahwa teori agensi mempelajari desain kontrak untuk memotivasi agen rasional untuk bertindak atas nama prinsipal ketika kepentingan agen akan bertentangan dengan kepentingan prinsipal. Menurut Hoesada (2020), teori agensi muncul ketika kegiatan bisnis suatu entitas tidak dikelola langsung oleh pemilik entitas dan 
seluruh hal mengenai manajemen diserahkan kepada agen. Baik prinsipal dan agen memiliki perannya masing-masing, prinsipal mendelegasikan wewenang pengambilan keputusan kepada agen serta menyediakan sumber daya untuk agen, sedangkan agen menggunakan sumber daya dari prinsipal untuk mengambil keputusan-keputusan dalam menjalankan perusahaan (Kopp, 2021). Atas peran tersebut prinsipal akan memperoleh hasil berupa perolehan laba, sedangkan agen akan menerima insentif seperti gaji dan bonus.

Terdapat dua permasalahan utama dalam hubungan keagenan. Pertama, masalah yang timbul karena adanya konflik kepentingan antara prinsipal dan agen serta sulit atau mahalnya biaya yang dikeluarkan ketika prinsipal ingin memantau perilaku agen yang sebenarnya. Kedua, masalah pembagian resiko yang muncul ketika prinsipal dan agen memiliki sikap yang berbeda dalam menangani resiko (Eisenhardt, 1989). Menurut Triyuwono (2018) permasalahan pada teori agensi terjadi ketika pihak agensi berupaya memaksimalkan kepentingan dirinya sendiri dan mengabaikan kepentingan prinsipal dimana tujuan utama suatu perusahaan adalah untuk memaksimalkan kesejahteraan pemilik modal. Agen dapat bersikap opotunistik atau mengutamakan kepentingan pribadi diatas kepentingan prinsipal sehingga untuk mengatasinya diperlukan penetapan insentif yang sesuai serta mengganggarkan biaya untuk melakukan pemantauan (Hill \& Jones, 1992).

Dalam menjalankan perusahaan, agen membuat keputusan-keputusan atau tindakantindakan untuk mendukung tercapainya tujuan perusahaan. Tindakan-tindakan tersebut dapat berupa aksi korporasi stock split atau pemecahan saham. Secara teori stock split tidak memberikan pengaruh apapun pada laporan keuangan perusahaan, namun melihat bagaimana kebijakan stock split terus menerus dilakukan menimbulkan pemikiran bahwa mungkin saja terdapat motivasi lain dibalik kebijakan tersebut. Sulit bagi pihak non-agen atau prinsipal untuk mengetahui motivasi/tujuan sebenarnya dibalik dilakukannya kebijakan stock split karena principal hanya bisa berpatokan secara pasti pada angka dalam laporan keuangan. Jika agen memiliki tujuan yang baik dan selaras dengan tujuan yang telah disepakati, maka stock split akan menimbulkan pengaruh baik bagi perusahaan seperti peningkatan nilai perusahaan. Sebaliknya kebijakan stock split juga bisa dimanfaatkan oleh agen untuk melakukan hal-hal yang menyimpang demi mencapai tujuan pribadinya, salah satunya yaitu dengan melakukan manajemen laba pada laporan keuangan perusahaan.

\section{Pengembangan Hipotesis}

Teori agensi menekankan permasalahan utama antara agen dan prinsipal sebagai perbedaan kepentingan diantara keduanya (Scott, 2015). Agen dapat bersikap oportunistik dengan mengutamakan tujuan pribadinya, sehingga untuk mengatasi tindakan tersebut diperlukan penetapan insentif bagi manajer dan biaya untuk melakukan pemantauan kinerja manajer (Hill \& Jones, 1992). Dalam hubungan antara agen dan prinsipal, manajer memiliki informasi yang lebih sempurna dibandingkan pemegang saham mengenai perusahaan karena manajer secara langsung menjalankan proses bisnis perusahaan. Kondisi ini menyebabkan adanya ketidakseimbangan informasi antara agen dan prinsipal atau sering disebut asimetri informasi. Adanya asimetri informasi memberikan peluang kepada agen untuk melakukan tindakan-tindakan yang tidak dapat diduga oleh prinsipal dengan memanfaatkan kelebihan informasi yang dimilikinya (Evitasari, 2020). Kondisi ini dimanfaatkan oleh manajer untuk melakukan manajemen laba. Untuk mencapai tujuan/insentif yang ingin dicapai, manajer melakukan manajemen laba dengan melakukan manipulasi laporan keuangan untuk menghasilkan laporan keuangan yang tampak baik di mata investor (prinsipal).

Stock split merupakan aksi korporasi perusahaan yang tidak memiliki dampak pada perubahan laporan keuangan, namun pada beberapa penelitian menunjukkan adanya hubungan antara stock split yang dilakukan perusahaan dengan aktivitas manajemen laba yang dilakukan oleh manajer. Penelitian-penelitian tersebut antara lain, penelitian oleh Boermawan \& Siregar (2013) yang menunjukkan bahwa perusahaan yang melakukan stock split terbukti melakukan manajemen laba yang mengalami kenaikan income pada periode pra-stock split. Penelitian oleh Chan et al. (2019) menunjukkan adanya adanya perubahan kinerja saham setelah stock split yang disebabkan oleh manajemen laba. 
Manajer memiliki informasi yang lebih sempurna dibandingkan dengan pemegang saham mengakibatkan momentum stock split digunakan untuk tujuan tertentu, sehingga manajer melakukan diskresinya dalam laporan keuangan dalam bentuk manajemen laba sebelum stock split dengan tujuan untuk menunjukkan laporan keuangan yang semakin baik. Informasi dari laporan keuangan dapat digunakan oleh pemegang saham existing dan pemegang saham potensial dalam mendukung keputusannya untuk berinvestasi saham perusahaan tersebut. Namun, tindakan manajemen laba yang dilakukan oleh manajer akan semakin meningkat setelah perusahaan melakukan stock split. Aktivitas stock split dapat mengalihkan perhatian pemegang saham terkait dengan prestasi perusahaan, sehingga kondisi ini dapat dimanfaatkan manajer untuk melakukan manajemen laba yang lebih tinggi. Dengan demikian, hipotesis pertama dalam penelitian ini adalah: $\mathrm{H}_{1}$ : Terdapat perbedaan manajemen laba sebelum dan sesudah stock split

Teori agensi memberikan pandangan bahwa permasalahan yang terjadi antara agen dan prinsipal bisa diatasi dengan menetapkan insentif yang tepat untuk agen (Hill \& Jones, 1992). Insentif atau kompensasi diberikan untuk mengatasi masalah konflik kepentingan antara agen dan prinsipal yang bertujuan untuk memberikan motivasi kepada agen untuk meningkatkan kinerja perusahaan (Hastanto, 2021). Kinerja operasi menunjukkan aktivitas manajer dalam memperoleh keuntungan dalam satu periode. Manajer berusaha untuk memiliki kinerja operasi yang baik sebelum stock split dilakukan dengan tujuan meyakinkan pemegang saham dan calon pemegang saham bahwa perusahaan dalam kondisi fundamental yang baik. Manajer menginginkan kebijakan stock split yang dilakukan sejalan dengan kinerja operasi yang dicapainya sebagai salah satu strategi pemegang saham tetap menyimpan dananya di perusahaan tersebut.

Boedhi \& Lidharta (2011) dan Hermawan (2017) menemukan bahwa terdapat perbedaan kinerja operasi sebelum dan sesudah stock split. Walaupun stock split secara teknis tidak berpengaruh terhadap laporan keuangan perusahaan, namun pada kenyataannya terdapat motifmotif tertentu yang melatarbelakangi manajer dalam melakukan kebijakan stock split. Kinerja operasi yang baik sebelum stock split dilakukan menunjukkan bahwa perusahaan memiliki strategi yang baik dalam mencapai keuntungan tertentu. Namun, kondisi tersebut dapat berubah setelah periode stock split terjadi. Dengan demikian, hipotesis kedua dalam penelitian ini adalah:

\section{$\mathrm{H}_{2}$ : Terdapat perbedaan kinerja operasi sebelum dan sesudah stock split}

Adanya perbedaan kepentingan antara manajer dan pemegang saham mengakibatkan manajer memiliki motif tertentu untuk kepentingan pribadinya. Stock split merupakan suatu bentuk aksi korporasi berupa pemecahan nilai nominal saham menjadi nilai yang lebih kecil (Hardiyan, 2020). Tindakan tersebut menunjukkan bahwa perusahaan mendapatkan kepercayaan pemegang saham karena mendapat respon positif pasar modal. Perusahaan dianggap memiliki fundamental dan kelangsungan perusahaan di masa mendatang yang tinggi.

Yaasiin (2017), Hadiwijaya \& Widjaja (2018), Puspita \& Yuliari (2019), dan Tanoyo (2020) menyimpulkan bahwa terdapat adanya perbedaan kinerja pasar sebelum dan sesudah dilakukan stock split. Kinerja pasar setelah stock split diharapkan dapat semakin meningkat karena perusahaan dianggap berhasil untuk menyeleraskan kepentingan pemegang saham dalam bentuk peningkatan kekayaan pemegang saham. Selain itu, kebijakan stock split yang dilakukan perusahaan menunjukkan perusahaan memiliki strategi yang baik dalam menjalankan perusahaan di masa mendatang. Kepercayaan pemegang saham ditunjukkan dengan kenaikan harga saham. Dengan demikian, hipotesis ketiga dalam penelitian ini adalah:

\section{$\mathrm{H}_{3}$ : Terdapat perbedaan kinerja pasar sebelum dan sesudah stock split}

\section{METODE}

Data yang digunakan dalam penelitian ini adalah data sekunder yang bersumber dari laporan keuangan perusahaan sektor non-keuangan dalam periode tahun 2013 s.d. 2019 yang diperoleh dari www.idx.co.id, www.idnfinancials.com dan harga saham yang bersumber dari www.finance.yahoo.com. Berdasarkan purposive sampling, sampel dalam penelitan ini adalah: 
Tabel 2 Sampel Penelitian

\begin{tabular}{|l|c|}
\hline \multicolumn{1}{|c|}{ Kriteria } & Jumlah \\
\hline $\begin{array}{l}\text { Perusahaan terdaftar di BEI yang melakukan stock split pada periode } \\
\text { tahun 2013-2019 per 31 Maret 2021 }\end{array}$ & 82 \\
\hline $\begin{array}{l}\text { Perusahaan terdaftar di BEI yang melakukan stock split pada periode } \\
\text { tahun 2013-2019 dengan status delisting BEI per 31 Maret 2021 }\end{array}$ & $(2)$ \\
\hline $\begin{array}{l}\text { Perusahaan sektor keuangan terdaftar di BEI yang melakukan stock split } \\
\text { pada periode tahun 2013-2019 }\end{array}$ & $(3)$ \\
\hline $\begin{array}{l}\text { Perusahaan terdaftar di BEI yang melakukan stock split pada periode } \\
\text { tahun 2013-2019 dengan status suspended per 31 maret 2021 }\end{array}$ & $(3)$ \\
\hline $\begin{array}{l}\text { Perusahaan yang memiliki data laporan keuangan tidak lengkap pada } \\
\text { periode tahun 2013 -2019 }\end{array}$ & $(10)$ \\
\hline Total Sampel & 64 \\
\hline
\end{tabular}

Sumber: Data diolah dengan SPSS 26 (2021)

Penelitian ini menggunakan variabel terikat yaitu manajemen laba, kinerja operasi dan kinerja pasar. Variabel manajemen laba diukur dengan proksi akrual diskresioner. Proksi manajemen laba dalam penelitian ini menggunakan model Kothari et al. (2005) sebagaimana Boermawan \& Siregar (2013); Firmansyah \& Irawan (2018), dan Starkova \& Adamko (2020). Manajemen laba dilakukan dengan menggunakan akrual diskresioner sebagaimana dalam model berikut:

$$
\frac{\text { Accruals }}{T A t-1}=\beta 0\left(\frac{1}{T A t-1}\right)+\beta 1\left(\frac{\Delta R E V}{T A t-1}\right)+\beta 2\left(\frac{P P E}{T A t-1}\right)+\beta 3 R O A+\varepsilon
$$

Dimana:
Accruals :
TA t-1 :
PPE : : Nilai kotor Plant, Property dan Equipment
ROA : $\quad$ Return on Assets perusahaan pada tahun t-1
$\varepsilon \quad$ : $\quad$ Nilai Residual

Akrual diskresioner didapatkan dari nilai residual $(\varepsilon)$ berdasarkan uji regresi model di atas. Selanjutnya, kinerja operasi dalam penelitian ini menggunakan proksi Returns on Assets (ROA) sebagaimana Dwilita \& Satrya (2018), Sondakh et al. (2019), dan Silvia (2020) sebagai berikut.

$$
\mathrm{ROA}=\frac{\text { Net Income }}{\text { Total Assets }}
$$

Selain itu, proksi tambahan kinerja operasi dalam penelitian ini menggunakan Laba per Saham / Earnings per Share (EPS) sebagaimana Boedhi \& Lidharta (2011); Yaasiin (2017) dan Dwilita \& Satrya (2018) yaitu:

$$
\text { EPS }=\frac{\text { Net Income }- \text { Preferences Dividend }}{\text { Weighted Average Number of Ordinary Shares Outstanding }}
$$

Kinerja pasar menggunakan proksi Tobin's $Q$ mengikuti Jumiari \& Julianto (2017); Rahmadi (2019); dan Setiawati \& Na'im (2000) dan Radhitiya \& Purwanto (2017). Tobin's $Q$ adalah rasio untuk mengukur kinerja perusahaan dengan membandingkan dua penilaian dari aset yang sama (Sudiyanto \& Puspitasari, 2010). Formula Tobin's $Q$ adalah sebagai berikut.

$$
\text { Tobin'sQ }=\frac{\text { (Total Market Value }+ \text { Total BV of Liabilities) }}{\text { Total BV of Assets }}
$$

Market Value $=$ Market Price per Share $\times$ Total Outstanding Shares 
Selain itu, proksi tambahan kinerja pasar dalam penelitian ini adalah Price to Book Value (PBV), yang dihitung dengan membandingkan harga saham dengan nilai buku perusahaan, sehingga tujuan dari penilaian PBV adalah untuk mengetahui apakah harga saham di pasar modal telah sesuai dengan nilai buku perusahaan yang seharusnya. Penelitian ini menggunakan proksi yang digunakan oleh Mahayati et al. (2021), Sondakh et al. (2019), dan Berlian et al. (2020), sebagai berikut:

$$
\begin{gathered}
\text { Price to Book Value }=\frac{\text { Market Price per Share }}{\text { Book Value per Share }} \\
\text { Book Value per Share }=\frac{\text { Total Equity }}{\text { Total Outstanding Shares }}
\end{gathered}
$$

Dalam penelitian ini, pengujian pertama dilakukan dengan melakukan uji normalitas dengan uji Kolmogorof Smirnov karena sampel terdiri dari 64 observasi. Pengujian yang kedua dilakukan dengan uji komparatif, apabila data berdistribusi normal maka dilakukan uji statistik parametrik berupa uji beda paired sample t-test sedangkan apabila data berdistribusi tidak normal maka akan dilakukan uji statistik non parametrik berupa Uji Wilcoxon matched pair test.

\section{HASIL}

Statistik dekriptif dari variabel yang digunakan dalam penelitian ini terdapat dalam Tabel 3 dan 4 sebagai berikut:

Tabel 3 Data Variabel Sebelum Stock Split

\begin{tabular}{|l|c|c|c|c|c|c|}
\hline \multicolumn{1}{|c|}{ Var } & Mean & Med & Std. Dev. & Min. & Max. & Obs. \\
\hline EPS t-1 & 521 & 98 & 2215 & -527 & 17621 & 64 \\
\hline ROA t-1 & 0,456 & 0,449 & 0,405 & $-2,029$ & 0,999 & 64 \\
\hline PBV t-1 & 0,609 & 0,349 & 0,912 & $-2,705$ & 4,177 & 64 \\
\hline Tobin's Q t-1 & 0,916 & 0,748 & 0,646 & 0,014 & 4,103 & 64 \\
\hline AEM t-1 & 0,000 & $-0,008$ & 0,137 & $-0,356$ & 0,467 & 64 \\
\hline
\end{tabular}

Sumber: Data diolah dengan SPSS 26 (2021)

Tabel 4 Data Variabel Setelah Stock Split

\begin{tabular}{|l|c|c|c|c|c|c|}
\hline \multicolumn{1}{|c|}{ Var } & Mean & Med & Std. Dev. & Min. & Max. & Obs. \\
\hline EPS t+1 & 66 & 33 & 112 & -109 & 475 & 64 \\
\hline ROA t+1 & 0,493 & 0,480 & 0,290 & $-0,947$ & 0,997 & 64 \\
\hline PBV t+1 & 4,052 & 2,133 & 5,172 & $-0,140$ & 22,547 & 64 \\
\hline Tobin's Q t+1 & 2,917 & 1,332 & 3,899 & 0,325 & 19,858 & 64 \\
\hline AEM t+1 & 0,000 & $-0,061$ & 0,915 & $-3,461$ & 6,1755 & 64 \\
\hline
\end{tabular}

Sumber: Data diolah dengan SPSS 26 (2021)

Tabel 5 menunjukkan ringkasan uji normalitas atas variabel yang digunakan dalam penelitian ini dengan menggunakan uji Kolmogorov-Smirnov.

Tabel 5 Uji Normalitas

\begin{tabular}{|l|c|c|c|c|}
\hline & Statistic & df & Sig. & \\
\hline Delta AEM & .363 & 64 & .000 & $* * *$ \\
\hline Delta ROA & .163 & 64 & .000 & $* * *$ \\
\hline Delta EPS & .363 & 64 & .000 & $* * *$ \\
\hline Delta Tobins Q & .242 & 64 & .000 & $* * *$ \\
\hline Delta PBV & .206 & 64 & .000 & $* * *$ \\
\hline
\end{tabular}

Sumber: Data diolah dengan SPSS 26 (2021) 
Berdasarkan Tabel 5 di atas, variabel AEM, ROA, EPS, Tobins Q, dan PBV sebaran datanya tidak berdistribusi normal, sehingga tidak memenuhi persyaratan untuk dilakukan uji statistika parametrik dan harus dilakukan dengan melakukan uji statistika non-parametrik. Penelitian ini menggunakan Uji Wilcoxon matched pairs test sebagai uji beda dalam menguji hipotesis yang telah ditentukan. Ringkasan hasil uji beda terdapat dalam Tabel 6 di bawah ini.

Tabel 6 Ringkasan Uji Beda
\begin{tabular}{|r|r|r|r|}
\hline & \multicolumn{1}{c|}{ Z } & \multicolumn{1}{c|}{ Sig. } & \\
\hline AEM t+1 - AEM Q t-1 & -2.762 & 0.006 & $* * *$ \\
\hline ROA t+1 - ROA t-1 & -1.144 & 0.253 & \\
\hline EPS t+1 - EPS t-1 & -4.31 & 0.000 & $* * *$ \\
\hline Tobin's Q t+1 - Tobin's Q t-1 & -5.624 & 0.000 & $* * *$ \\
\hline PBV t+1 - PBV t-1 & -6.581 & 0.000 & $* * *$ \\
\hline
\end{tabular}

Sumber: Data diolah dengan SPSS 26 (2021)

\section{Manajemen Laba}

\section{PEMBAHASAN}

Hasil pengujian hipotesis menunjukkan bahwa terdapat perbedaan nilai akrual diskresioner sebelum dan sesudah peristiwa stock split, sehingga terdapat praktek manajemen laba sebelum dan setelah stock split. Hasil Penelitian ini sejalan dengan Boermawan \& Siregar (2013) dan Chan et al. (2019). Hasil pengujian manajemen laba sebelum dan setelah terjadinya stock split yang terjadi di Indonesia tidak selalu sama dengan aktivitas tersebut di negara-negara lainnya, khususnya di negara maju sebagaimana temuan Chan et al. (2019) dengan menggunakan data di Spanyol. Hasil pengujian ini berbeda dengan temuan dari Yagüe et al. (2009) dengan menggunakan data perusahaan di Swiss. Oleh karena itu, aktivitas manajemen laba terkait dengan stock split dari suatu emiten tidak dapat digeneralisasi untuk kelompok negara tertentu.

Dalam teori agensi, manajer terkadang memiliki motif tertentu atau memilki sifat oportunistik dengan memanfaatkan informasi lebih yang dimilikinya untuk mencapai tujuan pribadi. Informasi asimetri dalam hubungan tersebut memberikan keterbatasan pada pemegang saham untuk mengetahui secara pasti motif sebenarnya dibalik kebijakan stock split yang dilakukan oleh manajer. Kondisi ini mengakibatkan potensi bagi manajer untuk melakukan tindakan yang tidak sejalan dengan kepentingan pemegang saham yaitu dengan melakukan manajemen laba.

Kebijakan stock split dianggap kebijakan yang baik oleh pemegang saham karena kebijakan tersebut mengindikasikan adanya kondisi perusahaan yang lebih baik di masa depan. Berdasarkan data dalam statistik deskriptif menunjukkan bahwa kecenderungan aktivitas manajemen laba meningkat setelah perusahaan melakukan stock split. Oleh karena itu, oleh manajer peristiwa stock split dapat dijadikan pengalih perhatian pemegang saham terkait dengan kondisi masa depan perusahaan. Namun, peristiwa tersebut dimanfaatkan oleh manajer untuk melakukan manajemen laba yang motifnya tidak diketahui oleh pemegang saham. Terdapat motif-motif yang mungkin dilakukan oleh manajer dalam melakukan manajemen laba yang lebih tinggi seperti bonus yang lebih tinggi, mendapatkan utang yang lebih besar dari kreditor ataupun adanya aktivitas penghindaran pajak ( Sakessia \& Firmansyah, 2020).

\section{Kinerja Operasional}

Berdasarkan pengujian hipotesis, penelitian ini menunjukkan bahwa tidak terdapat perbedaan kinerja operasi sebelum dan sesudah peristiwa stock split. Namun perhitungan dengan proksi tambahan EPS menunjukkan hasil yang sebaliknya yaitu terdapat perbedaan nilai sebelum dan sesudah dilakukan stock split. Hasil penelitian ini sejalan dengan penelitian oleh Soureka \& Muchlis (2013) dan Dwilita \& Satrya (2018), namun tidak sejalan dengan Boedhi \& Lidharta (2011) dan Hermawan (2017). Kinerja operasional perusahaan yang dihitung dengan menggunakan ROA menunjukkan bahwa perubahan kinerja perusahaan sebelum perubahan dan setelah perusahaan melakukan stock split tidak mengalami perubahan nilai aset secara signifikan. Sementara itu, kinerja operasional perusahaan yang dihitung dengan menggunakan EPS sangat dipengaruhi oleh jumlah saham yang beredar dan akan menunjukkan nilai EPS yang lebih rendah 
setelah perusahaan melakukan stock split. Kondisi ini menunjukkan bahwa agen tidak selalu memiliki motif implisit dibalik kebijakan stock split sehingga dianggap tidak terdapat penyalahgunaan kekuasaan akibat adanya asimetri informasi. Dalam teori agensi, manajer bertindak mewakili prinsipal dalam menjalankan perusahaan sehingga dalam kebijakan yang diambil pemegang saham senantiasa meminta persetujuan prinsipal dan tidak bergerak sesuai kemauan sendiri (Jensen \& Meckling, 1976). Disisi lain, tidak adanya peningkatan kinerja operasi setelah dilakukan kebijakan perusahaan yaitu stock split menunjukkan bahwa agen gagal dalam hal respon terhadap insentif. Kondisi ini mungkin terjadi saat prinsipal kurang bisa memenuhi insentif untuk agen sehingga motivasi agen untuk meningkatkan kinerja operasi tidak lebih baik dibandingkan dengan kinerja operasi sebelum dilakukan stock split.

Umumnya, kinerja operasi tidak berdampak terhadap kebijakan-kebijakan perusahaan yang berhubungan dengan pasar modal. Kinerja operasi cenderung merupakan aktivitas manajer dalam mengelola keefektivitasan dan keefisienan perusahaan dalam memaksimalkan sumber daya yang dimiliki. Perbedaan hasil pengujian proksi ROA dan EPS mungkin diakibatkan karena nilai EPS dihitung dengan membagi laba perusahaan dengan jumlah saham beredar dimana kebijakan stock split meningkatkan jumlah lembar saham beredar. Sementara perhitungan ROA, baik unsur nilai par maupun jumlah lembar saham bukan merupakan unsur untuk menghitung nilai ROA. Nilai ROA dihitung dengan membagi laba dengan total asset perusahaan. Berdasarkan statistik deskriptif, nilai rata-rata ROA sebelum dan setelah dilakukan stock split tidak berbeda secara signifikan, sedangkan nilai EPS secara rata-rata mengalami perubahan yang signifikan setelah perusahaan melakukan stock split. Kondisi yang terjadi di Indonesia sejalan dengan kondisi di negara berkembang lainnya seperti India bahwa kebijakan stock split tidak berhubungan dengan fundamental bisnis atau operasional perusahaan (Chavali \& Zahid, 2011).

\section{Kinerja Pasar}

Hasil pengujian hipotesis menunjukkan bahwa kinerja pasar sebelum dan setelah stock split menunjukkan terdapat perbedaan. Hasil pengujian dalam penelitian ini juga membuktikan bahwa penggunaan dua proksi yang berbeda dengan menggunakan Tobin's Q dan PBV menunjukkan hasil yang sejalan. Hasil penelitian ini sejalan dengan Yaasiin (2017), Hadiwijaya \& Widjaja (2018), Puspita \& Yuliari (2019), dan Tanoyo (2020), namun tidak sejalan dengan Soureka \& Muchlis (2013), Prijati \& Rachmawati (2019), dan Bagaskoro et al. (2019). Hasil pengujian ini menunjukkan bahwa pemegang saham memiliki keyakinan bahwa tindakan stock split yang dilakukan perusahaan menunjukkan adanya kondisi fundamental perusahaan yang semakin baik di masa mendatang. Terlepas dari adanya masalah keagenan, pemegang saham percaya bahwa manajer memiliki strategi-strategi terbaiknya untuk menyelaraskan kepentingan pemegang saham (Firmansyah et al., 2021). Manajer dianggap mampu untuk meningkatkan kekayaan pemegang saham sehingga respon pemegang saham menjadi lebih baik dengan kondisi perusahaan di masa depan.

Kondisi yang terjadi di Indonesia ternyata juga terjadi di negara maju seperti di Amerika bahwa pengumuman stock split juga menimbulkan reaksi positif pasar dan menunjukkan adanya efisiensi pasar yang terjadi (Shea \& Bacon, 2018). Adanya kebijakan stock split terkait dengan kebijakan perusahaan pada dasarnya untuk menarik minat investor dalam berinvestasi. Manajer mendapatkan kepercayaan pasar terkait dengan fundamental perusahaan dan kondisi perusahaan di masa depan yang semakin baik. Respon pasar dapat mengakibatkan adanya aliran sumber daya tambahan dari investor baru sehingga mengakibatkan perusahaan menerima lebih banyak modal untuk meningkatkan investasi dalam aset-aset yang produktif (Al 'Alam \& Firmansyah, 2020; Firmansyah \& Triastie, 2020). Strategi perusahaan tersebut dianggap sebagai cara untuk meningkatkan kinerja perusahaan dalam rangka meningkatkan kemakmuran pemegang saham.Kebijakan stock split baik di negara maju maupun di negara berkembang menunjukkan kecenderugan yang sama yaitu adanya kepercayaan investor terhadap kebijakan manajemen dalam mengelola perusahaan dengan baik. Selain itu, investor percaya bahwa kebijakan stock split menunjukkan perusahaan memiliki strategi untuk meningkatkan kemajuan perusahaan dan keberlangsungan perusahaan di masa mendatang. Kebijakan stock split yang dilakukan olah manajer dalam perusahaan dianggap dapat menyelaraskan kepentingan pemegang saham dalam 
meningkatkan kekayaannya.

\section{KESIMPULAN}

Penelitian ini menemukan bahwa kebijakan stock split yang dilakukan oleh perusahaan digunakan sebagai peristiwa bagi manajer untuk melakukan manajemen laba yang lebih besar. Adanya perbedaan kepentingan antara manajer dan pemegang saham, mengakibatkan manajer memiliki motif-motif tertentu dalam aktivitas manajemen laba setelah stock split dilakukan. Sementara itu, walaupun kebijakan ini tidak mengakibatkan adanya perbaikan kinerja operasi, namun kebijakan ini menunjukkan adanya kepercayaan dari pemegang saham bahwa manajer selalu berusaha untuk meningkatkan fundamental dan masa depan perusahaan yang lebih baik. Kebijakan stock split dianggap pemegang saham bahwa manajer mampu menyelaraskan kepentingannya dengan kepentingan pemegang saham.

Beberapa keterbatasan dalam penelitian ini antara lain sampel penelitian terbatas pada perusahaan BEI pada sektor non-keuangan saja sehingga tidak merepresentasikan seluruh perusahaan BEI sepenuhnya. Hasil yang berbeda mungkin saja dapat terjadi jika mengikutkan sampel perusahaan keuangan. Pengambilan sampel keuangan terbatas pada rentang waktu yang hanya 7 tahun yaitu dari tahun 2013 hingga 2019. Terdapat beberapa perusahaan yang tidak memiliki data laporan keuangan yang lengkap pada periode stock split tahun 2019 sehingga dieliminasi dari daftar sampel yang diuji.

Penelitian selanjutnya dapat menggunakan data perusahaan sektor keuangan maupun sektor non-keuangan dengan periode penelitian yang lebih panjang sehingga hasil dari penelitian lebih komprehensif dan dapat menghasilkan hasil pengujian yang lebih baik. Penelitian ini juga mengindikasikan bahwa untuk perusahaan yang memiliki kebijakan stock split sebaiknya menggunakan peristiwa tersebut untuk meningkatkan kinerja operasinya. Sementara itu, penelitian ini juga berguna bagi investor dan calon investor dapat digunakan sebagai analisis tambahan dalam pengambilan keputusan investasi dalam emiten di pasar modal yang melakukan stock split.

\section{REFERENSI}

Al 'Alam, M. P. A., \& Firmansyah, A. (2020). The effect of financial reporting quality, debt maturity, political connection, and corporate governance on investment efficiency: evidence from Indonesia. International Journal of Innovation, Creativity and Change, 7 (6), 39-56.

Adisetiawan, R., \& Atikah. (2018). Does stock split influence to liquidity and stock return? (empirical evidence in the Indonesian capital market). Asian Economic and Financial Review, 8(5), 682-690. https://doi.org/10.18488/journal.aefr.2018.85.682.690

Bagaskoro, B. S., A, A. F., \& Widagdo, A. K. (2019). The effect of stock split on liquidity stock in companies which listed on BEI 2007-2015. International Journal of Economics, Business and Management Research, 3(11), 160-169.

Berlian, N., Puspita, N. V., \& Yuliari, K. (2020). Analisis fundamental dan nilai saham dengan metode price earning ratio (per) dan price to book value (PBV) dalam keputusan investasi (perusahaan semen yang terdaftar di Bursa Efek Indonesia (BEI) periode 2016-2018). Jurnal Cendekia Akuntansi, 1(2), 42-57.

Boedhi, S., \& Lidharta, P. D. (2011). Analisis perbedaan kinerja keuangan sebelum dan sesudah stock split pada perusahaan yang terdaftar di Bursa Efek Indonesia. Jurnal Spread, 1(1), 6273.

Boermawan, C., \& Siregar, S. V. (2013). Hubungan stock split dengan manajemen laba pada perusahaan yang terdaftar di Bursa Efek Indonesia Tahun 2001-2011. Jurnal Akuntansi Multiparadigma, 4(1), 101-111.

Burnwal, A., \& Rakshit, D. (2019). Announcement effect of stock split on price behaviour and market liquidity of shares : a study. Journal of Xi'an University of Architecture \& Technology, 11(12), 659-671. 
Chan, K., Li, F., \& Lin, T. C. (2019). Earnings management and post-split drift. Journal of Banking and Finance, 101, 136-146. https://doi.org/10.1016/j.jbankfin.2019.02.004

Chavali, K., \& Zahid, Z. (2011). Impact of stock splits on stock price performance of selected companies in Indian context. Afro-Asian Journal of Finance and Accounting, 2(3), 270-282. https://doi.org/10.1504/AAJFA.2011.041633

Cui, C., Li, F. W., Pang, J., \& Xie, D. (2020). A behavioral signaling explanation for stock splits: evidence from China. SSRN Electronic Journal, February. https://doi.org/10.2139/ssrn.3541201

Dwilita, H., \& Satrya, M. H. (2018). Penilaian kinerja keuangan perusahaan pada pasar modal indonesia sebelum dan setelah melakukan stock split saham. Jurnal Akuntansi Bisnis \& Publik, 8(2), 140-157.

Eisenhardt, K. M. (1989). Agency theory: an assessment and review. Academy of Management Review, 14(1), 57-74.

Evitasari. (2020). Pengertian asimetri. Terraveu. https://www.terraveu.com/pengertian-asimetri/

Firmansyah, A., \& Irawan, F. (2018). Adopsi IFRS, manajemen laba akrual dan manajemen laba riil. Assets: Jurnal Akuntansi Dan Pendidikan, 7(2), 81-94. https://doi.org/10.25273/jap.v7i2.3310

Firmansyah, A., \& Irawan, F. (2019). Do IFRS adoption and corporate governance increase accounting information quality in Indonesia? Accounting Analysis Journal, 8(1), 59-65. https://doi.org/10.15294/aaj.v8i1.27740

Firmansyah, A., \& Triastie, G. A. (2020). The role of corporate governance in emerging market: Tax avoidance, corporate social responsibility disclosures, risk disclosures, and investment efficiency. Journal of Governance and Regulation, 9(3), 8-26. https://doi.org/10.22495/jgrv9i3art1

Hadiwijaya, C., \& Widjaja, I. (2018). Analisis perbandingan abnormal return dan likuiditas saham sebelum dan sesudah stock split pada perusahaan yang terdaftar di Bursa Efek Indonesia periode 2010-2015. Jurnal Manajemen Bisnis Dan Kewirausahaan, 02(1), 1-10.

Hardiyan, Y. (2020). Pengertian stock split dan manfaatnya. Big Alpha. https://bigalpha.id/news/pengertian-stock-split-dan-manfaatnya\#

Hastanto. (2021). Taori keagenan (agency theory). https://www.hestanto.web.id/teori-keagenanagency-theory/

Hermawan, P. R. (2017). Analisis perbedaan kinerja keuangan sebelum dan sesudah stock split pada perusahaan manufaktur yang terdaftar di Bursa Efek Indonesia periode 2012-2015. Simki-Economic, 1(7), 1-11.

Hill, C. W. L., \& Jones, T. M. (1992). Stakeholder-agency theory. Journal of Management Studies, 29(2), 22-2380. https://doi.org/10.5840/iabsproc1997863

Hoesada, J. (2020). Teori keagenan. KSAP. http://www.ksap.org/sap/wpcontent/uploads/2020/09/MAJALAH-MAYA-KSAP-1-OKTOBER-2020.pdf

https://investasi.kontan.co.id/. (2021). Wah pandemi Covid-19 picu pertumbuhan jumlah investor pasar modal dan reksadana. https://investasi.kontan.co.id/news/wah-pandemi-covid-19picu-pertumbuhan-jumlah-investor-pasar-modal-dan-reksadana

Ismail, I. (2021). Intial Public Offering (IPO) adalah: proses dan alasan perusahaan memilih IPO. Accurete. https://accurate.id/bisnis-ukm/ipo-adalah/

Jensen, M. C., \& Meckling, W. H. (1976). Theory of the firm: managerial behaviour, agency cost and ownership structure. Journal of Financial Economics, 3, 305-360. 
Jumiari, N. K. V., \& Julianto, I. P. (2017). pengaruh intellectual capital, kinerja keuangan, dan kebijakan keuangan terhadap nilai perusahaan. Jurnal Ilmiah Akuntansi dan Humanika, 10(3), 276-287.

Kopp, C. M. (2021). Agency theory. Investopedia2. https://www.investopedia.com/terms/a/agencytheory.asp

Kothari, S. P., Leone, A. J., \& Wasley, C. E. (2005). Performance matched discretionary accrual measures. Journal of Accounting and Economics, 39(1), 163-197. https://doi.org/10.1016/j.jacceco.2004.11.002

Mahayati, F., Fatonah, S., \& Meilisa, R. (2021). Pengaruh return on equity (ROE) dan debt to equity ratio (DER) terhadap nilai perusahaan (PBV) pada perusahaan manufaktur sub sektor logam dan sejenisnya yang terdaftar di BEI. Jurnal Valuasi: Jurnal Ilmiah Ilmu Manajemen Dan Kewirausahaan, 1(1), 258-267.

Nurdin, F., \& Abdani, F. (2020). The effect of profitability ratio, solvability ratio, market ratio on stock return. Journal of Accounting Auditing and Business, 3(2), 52-64.

Paramitha, D. (2019). Analisis reaksi pasar atas pengumuman stock split. E-Jurnal Akuntansi Universitas Udayana, 27, 1897-1924. https://doi.org/10.24843/eja.2019.v27.i03.p10

Pratiwi, A., Norisanti, N., \& Samsudin, A. (2020). Analisis pengaruh harga saham terhadap perolehan laba (studi pada perusahan yang melakukan stock split yang terdaftar Di Bursa Efek Indonesia). Syntax Idea, 2(9), 1689-1699.

Prijati, \& Rachmawati, N. L. (2019). Perbedaan harga saham dan volume perdagangan saham sebelum dan sesudah stock split. Jurnal Ilmu Dan Riset Manajemen, 8(2), 1-15.

Puspita, N. V., \& Yuliari, K. (2019). Analisis pengaruh stock split terhadap harga saham, abnormal return dan risiko sistematik saham perusahaan (studi pada perusahaan yang terdaftar di BEI 2016-2018). Ekonika: Jurnal Ekonomi Universitas Kadiri, 4(1), 95-110. https://doi.org/10.30737/ekonika.v4i1.335

Quast, J. (2021). Investing in 2021? these 3 stocks are riding unstoppable trends. The Motley Fool. https://www.fool.com/investing/2021/05/23/investing-in-2021-these-3-stocks-are-ridingunstop/

Radhitiya, E., \& Purwanto, A. (2017). Pengaruh mekanisme corporate governance pada struktur kepemilikan, faktor internal, dan faktor eksternal perusahaan terhadap nilai perusahaan (tobin's q). Diponegoro Journal of Accounting, 6(1), 1-13.

Rahmadi, Z. T. (2019). Pengaruh net interest margin, non performing loan dan capital adequency ratio terhadap nilai perusahaan dengan tobin's q sebagai indikator pengukur pada perusahaan perbankan yang terdaftar di Bursa Efek Indonesia Periode 2016-2018. Khazanah Ilmu Berazam, 2(4), 634-643.

Sari, E. (2018). Prinsip going concern pada akuntansi perusahaan. Jtanzilco. https://www.jtanzilco.com/blog/detail/1 199/slug/prinsip-going-concern-dalam-akuntansiperusahan

Scott, W. R. (2015). Financial accounting theory. Seventh Edition. Pearson Prentice Hall: Toronto.

Setiawati, L., \& Na'im, A. (2000). Manajemen laba. Jurnal Ekonomi Dan Bisnis Indonesia, 15(4), 424-441.

Shea, B. P., \& Bacon, F. W. (2018). Stock split announcement: a test of market eficiency. Institute for Global Business Research Conference Proceeding, 2(1), 153-158.

Silvia, D. (2020). Analisa pebandingan economi value added (EVA) dan return on asset (ROA) dalam menilai kinerja perusahaan. Jurnal Akuntansi \& Keuangan, 11(1), 1-17. 
Sondakh, P., Saerang, I., \& Samadi, R. (2019). Pengaruh struktur modal (ROA, ROE dan DER) terhadap nilai perusahaan (PBV) pada perusahaan sektor properti yang terdaftar di BEI (periode 2013-2016). Jurnal EMBA: Jurnal Riset Ekonomi, Manajemen, Bisnis Dan Akuntansi, 7(3), 3079-3088. https://doi.org/10.35794/emba.v7i3.24196

Soureka, N. S., \& Muchlis, T. I. (2013). Stock performance analysis before and after stock split on basic industry and chemical in Indonesia. Working Paper.

Starkova, L., \& Adamko, P. (2020). Application of the kothari model to assess the existence of earnings management in enterprises in the Czech Republic. International Scientific Conference on Economic and Social Development, 4(1), 820-828.

Sudiyanto, B., \& Puspitasari, E. (2010). Tobin's Q dan Altman Z-Score sebagai indikator pengukuran kinerja perusahaan. Kajian Akuntansi, 2(1), 9-21.

Tambunan, D. (2020). Investasi saham di masa pandemi covid-19. Widya Cipta: Jurnal Sekretari Dan Manajemen, 4(2), 117-123.

Tanoyo, A. A. (2020). Analisis Pengaruh stock split terhadap volume perdagangan, harga saham, dan abnormal return pada perusahaan yang terdaftar di BEI Periode 2017-2018. Jurnal Manajemen Bisnis Dan Kewirausahaan, 4(1), 84-90.

Tari, D. N. (2020). Tumbuh 22 persen, investor pasar modal tembus 3 juta akun. Market Bisnis. https://market.bisnis.com/read/20200810/7/1277162/tumbuh-22-persen-investor-pasarmodal-tembus-3-juta-akun

Thakur, M. (2021). Agency problem. Wall Street Mojo. https://www.wallstreetmojo.com/agencyproblem/

Triyuwono, E. (2018). Proses kontrak, teori agensi, dan corporate governance. Working Paper. https://ssrn.com/abstract=3250329

Tuovila, A. (2020). Earnings management. Investopedia. https://www.investopedia.com/terms/e/earnings-management.asp

Warren, C. S., Reeve, J. M., \& Duchac, J. E. (2016). Financial and Managerial Accounting (Vol. $13 \mathrm{e})$. Cengage Learning.

Weygandt, J. J., Kieso, D. E., \& Kimmel, P. D. (2015). Principles of financial accounting. Jerry J. Weygandt, Donald E. Kieso, Paul D. Kimmel. (3e ed.). Wiley.

Yaasiin, F. N. (2017). Analisis kinerja keuangan perusahaan dan reaksi pasar sebelum dan sesudah stock split pada perusahaan yang terdaftar di Bursa Efek Indonesia Tahun 20102014. Tesis, Fakultas Ekonomi dan Bisnis, Universitas Sumatera Utara.

Yagüe, J., Gómez-Sala, J. C., \& Poveda-Fuentes, F. (2009). Stock split size, signaling and earnings management: evidence from the Spanish Market. Global Finance Journal, 20(1), 31-47. https://doi.org/10.1016/j.gfj.2009.03.004

www.financialexpress.com. (2021). How would rising Covid cases impact your equity investments? Financial Express. https://www.financialexpress.com/money/how-wouldrising-covid-cases-impact-your-equity-investments/2257133/

www.mncsekuritas.id. (2021). Aksi korporasi penggerak harga saham. MNC Sekuritas. https://www.mncsekuritas.id/pages/aksi-korporasi-penggerak-harga-saham 